University of Nebraska - Lincoln

DigitalCommons@University of Nebraska - Lincoln

\title{
Discovery of Crepidodera bella Parry (Coleoptera: Chrysomelidae: Alticini) in Maryland and Redescription
}

\author{
Ainsley Seago \\ Cornell University, Ithaca, New York and National Museum of Natural History Research Training Program \\ Smithsonian Institution, Washington, D.C. 20560, U.S.A. \\ Steven W. Lingafelter \\ Systematic Entomology Laboratory, PSI, ARS, USDA and National Museum of Natural History, MRC-168, \\ Smithsonian Institution, Washington, D.C. 20560, U.S.A.
}

Follow this and additional works at: https://digitalcommons.unl.edu/systentomologyusda

Part of the Entomology Commons

Seago, Ainsley and Lingafelter, Steven W., "Discovery of Crepidodera bella Parry (Coleoptera: Chrysomelidae: Alticini) in Maryland and Redescription" (2003). USDA Systematic Entomology Laboratory. 30.

https://digitalcommons.unl.edu/systentomologyusda/30

This Article is brought to you for free and open access by the Entomology Collections, Miscellaneous at DigitalCommons@University of Nebraska - Lincoln. It has been accepted for inclusion in USDA Systematic Entomology Laboratory by an authorized administrator of DigitalCommons@University of Nebraska - Lincoln. 


\title{
DISCOVERY OF CREPIDODERA BELLA PARRY (COLEOPTERA: CHRYSOMELIDAE: ALTICINI) IN MARYLAND AND REDESCRIPTION
}

\author{
Ainsley SEAgo ${ }^{1}$ and Steven W. Lingafelter ${ }^{2}$ \\ ${ }^{1}$ Cornell University, Ithaca, New York and National Museum of \\ Natural History Research Training Program \\ Smithsonian Institution, Washington, D.C. 20560, U.S.A.; and \\ ${ }^{2}$ Systematic Entomology Laboratory, PSI, ARS, USDA and \\ National Museum of Natural History, MRC-168, \\ Smithsonian Institution, Washington, D.C. 20560, U.S.A.
}

\begin{abstract}
Crepidodera bella Parry (Coleoptera: Chrysomelidae: Alticini), previously known only from Florida, South Carolina, Alabama, and Louisiana, is discovered in central Maryland. This species is sympatric with $C$. browni Parry on Salix nigra growing along swamps in the McKee-Besher Wildlife Management Area $\left(39^{\circ} 04^{\prime} 30^{\prime \prime} \mathrm{N}, 77^{\circ} 23^{\prime} 00^{\prime \prime} \mathrm{W}\right)$. Morphological features of the integument and genitalia are described and compared to $C$. browni.
\end{abstract}

Key words: Crepidodera, Chrysomelidae, flea beetle, Maryland, Salix, willow, redescription, range extension.

Crepidodera Chevrolat is a large genus of flea beetles (Coleoptera: Chrysomelidae: Alticini), containing over 80 described species (Blackwelder, 1946; Parry, 1986; Gruev and Döberl, 1997), although those in South America may be incorrectly assigned to the genus. Most Crepidodera are easily recognized by the dorsal coloration (metallic green, copper, or bronze), the pronotal transverse depression with two terminal longitudinal depressions above the posterior margin, and the mostly glabrous elytra with seriate punctation. Unlike most flea beetles of the temperate region, adult Crepidodera feed on the leaves of shrubs or trees, particularly the Salicaceae.

Parry (1986) described C. browni and C. bella, among others, in a revision of Crepidodera for the United States and Canada. The former species is widespread from Texas to Canada and throughout the northeastern United States and the Ohio valley. The type locality is Plummers Island, Maryland, near Washington DC. The latter species, C. bella, was known from only 39 specimens from the southeastern United States, in Florida, South Carolina, Alabama, and Louisiana. On several expeditions in 1999 and 2001 to the McKee-Besher Wildlife Management Area, a few miles west of the $C$. browni type locality, 140 specimens of Crepidodera were taken on willow (Salix nigra Marsh) growing along swamp margins. Examination of the material revealed two species coexisting on the trees: the abundant $C$. browni and the less common C. bella.

Crepidodera bella is redescribed and compared directly with $C$. browni. The aedeagus, spermatheca, vaginal palpus, and tignum are described and illustrated.

MATERIAL AND METHODS

Most of the type series of $C$. browni and $C$. bella were borrowed from the Canadian National Collection (CNCI), Field Museum of Natural History (FMNH), California Academy 
of Sciences (CASC), and the Smithsonian Institution (USNM). Genitalic dissections were performed primarily upon specimens collected in 1999 and 2001 from the McKee-Besher Wildlife Area. After gentle washing in a mild potassium hydroxide solution, aedeagi were mounted on points, while the female genitalia (vaginal palpi, spermathecae, tigna) were placed in glass micro-vials. Structural terms used in the diagnosis and redescription follow Konstantinov (1998) and Lingafelter et al. (1998). Illustrations were prepared by pencil on drafting film by the senior author.

\section{Crepidodera bella Parry}

Figs. 1b, 2b, 3b, 4b, 5b, 6

Diagnosis. Crepidodera bella is recognized by the coarse punctures along the upper vertex and posterior middle vertex of the head (sometimes mostly concealed by the anterior margin of the pronotum), the reflective red copper or bronze integument (very dark and less metallic in some specimens), the somewhat swollen elytral humerus and basal one-fourth, the complete elytral lateral margin, not obscured from above by expansion of the elytra, and characters of the genitalia. Most specimens of $C$. browni, which is sympatric, are metallic green, but some specimens have a coppery iridescence identical to $C$. bella. These can be distinguished most easily by their lack of punctures on the occiput and middle vertex of the head and characters of the genitalia. The aedeagus of $C$. bella (Fig. 1b) is moderately to strongly convex. In C. browni (Fig. 1a) the aedeagus is similar in shape, but straighter. In C. bella, the middle dorsal apical aedeagal flap (Fig. 3b) has convergent margins at the base, while in C. browni the middle apical flap margins are parallel at the base (Fig. 3a). The venter of the aedeagus has weak middle and apical depressions in $C$. bella (Fig. 2b), while in C. browni, the middle depression is more prominent and two apical and one subapical depressions are present (Fig. 2a). Some specimens of $C$. bella have a slightly asymmetrical aedeagal apex as illustrated (Figs. 2b, 3b). The vaginal palpi in $C$. bella (Fig. 4b) are short and X-shaped, whereas they are longer with convergent apices in $C$. browni (Fig. 4a). The spermatheca in $C$. bella, like C. browni, is globular (Fig. 6), but has the pump not curving back towards the base of the receptacle and is parallel to the sclerotized spermathecal duct. In C. browni, the pump apex is curved downward. In $C$. bella, there is a weak inflection at the insertion of the pump into the receptacle which is lacking in $C$. browni.

Description. Body length: $2.1 \mathrm{~mm}$ (small males) to $3.5 \mathrm{~mm}$ (large females). Most specimens with reddish copper or brass sheen above, some also with vague green iridescence or very dark with reduced sheen, glabrous dorsally. Dark reddish-brown to black on venter. Head bronze to copper iridescent with some green reflections along lower frons, gena, and anterior to antennal insertion. Heavily punctate in 2-3 poorly defined rows along occiput (sometimes mostly obscured by anterior edge of pronotum). Very fine punctures just above antennal calli at midline of head. Eye margins coarsely punctate. Antennal calli large, posterior margins converging to form broad "V". Frontal ridge well-defined and narrow. Antennae dirty yellow in most specimens, darker brown in specimens collected in late summer. Scape and second antennomere inflated, third very narrow, remainder gradually thickened apically and larger towards apical segment. Numerous white hairs coating antenna. Eye large, round, occupying two-thirds of head from lateral view; separated dorsally from opposite eye by its height or more. Labium and maxilla testaceous in most specimens to dark brown in specimens from late summer. Labrum and clypeus piceous, rectangular. 2-4 large punctures and 2-6 long, pale hairs present on labrum. Mandible acute, yellow to reddish-brown with darker apex. Thorax 


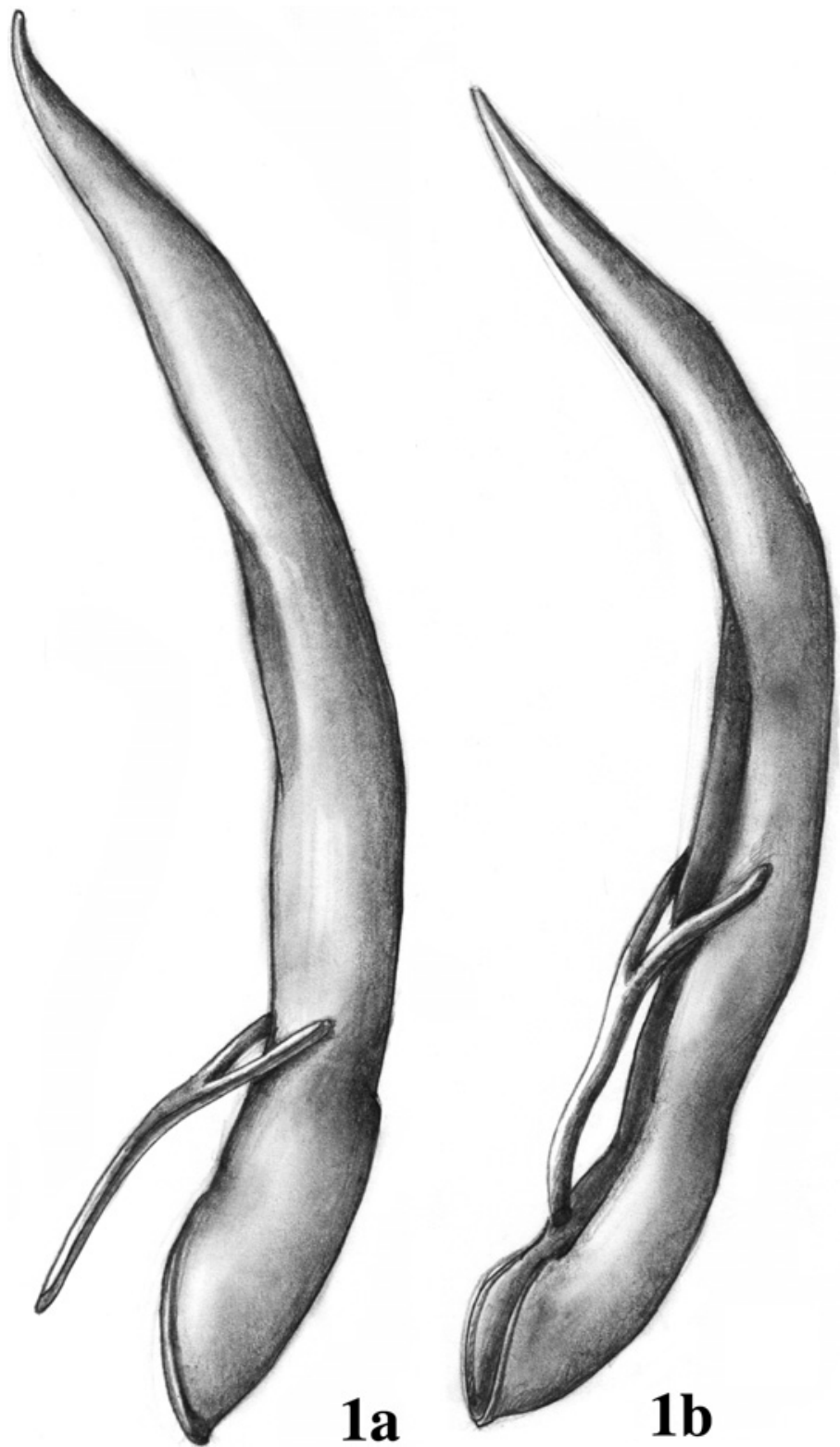

Fig. 1. Aedeagus in lateral view. a, C. browni Parry; b, C. bella Parry. 



Fig. 2. Aedeagus in ventral view. a, C. browni Parry; b, C. bella Parry. Fig. 3. Apex of aedeagus in dorsal view. a, C. browni Parry; b, C. bella Parry.

with pronotum metallic copper to bronze, green reflections on margins of some specimens. Coarse, dense punctures irregular in distribution and size, most smaller than those of elytra. Pronotum about $1.4 \times$ broader than long in males $(\mathrm{N}=13)$; about $1.6 \times$ broader than long in females $(\mathrm{N}=8)$. Lateral margins broadly rounded with anterolateral and posterolateral corners expanded, each bearing a long, white seta. Posterior margin of pronotum curved broadly toward scutellum; anterior margin straight. Pronotum with poorly defined ante-basal transverse depression flanked by two distinct, parenthetical shaped, longitudinal depressions that run to posterior margin. Scutellum dark bluish, weakly iridescent, glabrous, darker than surrounding integument. Mesosternal intercoxal process broad. Elytron copper-bronzy metallic in most specimens, some specimens with greenish iridescence on sides, some very dark, nearly black with reduced metallic sheen. Anterior one-fourth swollen dorsally, lateral margin explanate, visible for entire border. Each elytron with eleven striae of large punctures converging at apex but absent from swollen humeral region. Aedeagus (Figs. 1b, 2b, 3b) moderately to strongly curved in lateral view. Dorsal apex with moderately recessed inner flap with elevated margins that are convergent posteriorly towards base of flap. Aedeagus venter with shallow impression medially and apically. Female genitalia: Tignum (Fig. 5b) with long base and apex Y-shaped with approximately 25 short, stout setae. Vaginal palpi (Fig. 4b) relatively short and symmetrically $\mathrm{X}$-shaped with divergent arms apically and basally and 16- 



Fig. 4. Vaginal palpi. a, C. browni Parry; b, C. bella Parry. Fig. 5. Tignum. a, C. browni Parry; b, C. bella Parry. Fig. 6. Spermatheca of $C$. bella Parry.

20 long setae at apex. Spermatheca (Fig. 6) with globular, nearly round receptacle. Sclerotized spermathecal duct initially lying alongside the receptacle, but divergent and parallel with pump for remainder. Spermathecal pump as long as receptacle, straight for one-fourth its length, diverging at right angle parallel to sclerotized spermathecal duct for its remainder. Base of pump with inflection at its insertion to receptacle.

Discussion. A total of 25 specimens of $C$. bella were collected in the McKee-Besher Wildlife Management Area on willow (Salix nigra) growing along swamp margins. Specimens were collected from May to August from late morning to mid-afternoon by sweeping and beating the willow branches. This species co-exists with the more abundant $C$. browni Parry on the same trees and appears to have no niche distinction from that species. This enigmatic and unexpected population of $C$. bella represents a considerable northern range extension of over 500 miles (805 kilometers) across three states.

Material examined. The type series of Crepidodera bella Parry (1986) was examined but the specimen data are not repeated here. New specimen records, all from UNITED STATES, Maryland, Montgomery County, McKee-Besher Wildlife Management Area $\left(39^{\circ} 04^{\prime} 30^{\prime \prime} \mathrm{N}\right.$, $\left.77^{\circ} 23^{\prime} 00^{\prime \prime} \mathrm{W}\right)$ and deposited in USNM ( $\mathrm{m}=$ male; $\mathrm{f}=$ female) include: 11 July 1999, N. E. Woodley, on Salix sp. (4m, 2f); 11 July 1999, S. W. Lingafelter (1m, 1f); 28 May 2001, S. W. 
Lingafelter \& N. E. Woodley (3m); 31 May 2001, N. E. Woodley, on Salix (1f); 10 June 2001, S. Lingafelter \& A. Seago, sweeping Salix (1f); 10 June 2001, S. Lingafelter \& A. Seago, on Salix tree \#2 (3m, 1f); same, but \#4 (3m, 2f); 4 August 2001, on Salix nigra, S. W. Lingafelter $(1 \mathrm{~m}, 2 \mathrm{f})$.

\section{ACKNOWLEDGMENTS}

The authors gratefully acknowledge Alexander Konstantinov (Systematic Entomology Lab, USDA) for his help and support and comments on the manuscript. We thank Norman Woodley (Systematic Entomology Lab, USDA) for collecting and preparing additional specimens of Crepidodera. Laurent LeSage (CNCI), Philip Parrillo and Al Newton (FMNH), and Roberta Brett and David Kavanaugh (CASC) each provided specimens from their institutional collections for this study. We thank Ronald Ochoa and Allen Norrbom (both SEL, USDA), Charlie Staines (USNM), and an anonymous reviewer for comments that improved this manuscript.

This work was completed while the senior author was a participant in the 2001 Research Training Program at the National Museum of Natural History, Smithsonian Institution. Funding for the study was provided by the National Science Foundation, award \# DBI-9820303.

\section{LITERATURE CITED}

Blackwelder, R. E. 1946. Checklist of the Coleopterous Insects of Mexico, Central America, the West Indies, and South America. Part 4. Smithsonian Institution United States National Museum Bulletin 185: 551-1492.

Gruev, B. and M. Döberl. 1997. General distribution of the flea beetles in the Palaearctic Subregion (Coleoptera, Chrysomelidae: Alticinae). Scopolia 37: 496 pp.

Konstantinov, A. S. 1998. On the structure and function of the female genitalia in flea beetles (Coleoptera: Chrysomelidae: Alticinae). Proceedings of the Entomological Society of Washington 100(2): 353360.

Lingafelter, S. W., A. S. Konstantinov, and J. E. Lee. 1998. Systena Chevrolat (Coleoptera: Chrysomelidae: Alticinae): notes on nomenclature, redescription of the genus, and a preliminary discussion of characters and phylogenetic relationships. Proceedings of the Entomological Society of Washington 100(3): 467-483.

Parry, R. H. 1986. The systematics and biology of the flea beetle genus Crepidodera Chevrolat (Coleoptera: Chrysomelidae) in America north of Mexico. Insecta Mundi 1(3): 156-196.

Received 1 November 2002; accepted 21 March 2003. 